How Do Marital Status And Gender Affect The PRR To A University Degree In Australia?

Wright, Sarah

Contemporary Issues in Education Research; Jul 2011; 4, 7; ProQuest pg. 19

\title{
How Do Marital Status And Gender Affect The PRR To A University Degree In Australia?
}

Sarah Wright, Australian Catholic University, Australia

\begin{abstract}
While Australian evidence suggests that the Private Rate of Return (PRR) to a university degree in Australia has gradually declined with increases in the cost of higher education, these studies have only measured the PRR for the average male and average female. This paper uses income data from the ABS Income and Housing Survey (2003-04) CURF to measure the impact of the 2005 increase in HECS fees on the PRR based on gender and marital status. This paper shows that the return to a university degree is largely affected by both gender and marital status and studies that measure the PRR to a university degree for single males and single females with no dependent children underestimate the PRR for most male graduates and overestimate the PRR of female graduates.
\end{abstract}

Keywords: higher education funding; labor markets; HECS; income contingent scheme; economics; human capital; private rate of return; social rate of return

\section{INTRODUCTION}

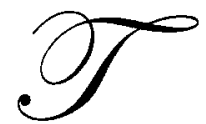

he decision-making involved in choosing whether or not to go to a university and to privately invest in human capital is complex. Numerous studies have shown that there is a positive relationship between the level of earnings and education and therefore suggest that students should invest in a university education. According to Chia (1990), students should base their decisions on the Private Rate of Return (PRR) to a university degree. That is the minimum rate of return that an individual would need to earn to consider higher education a profitable investment. The Private Rate of Return (also known as the Private Internal Rate of Return) is the rate of return on an individual's investment in higher education expressed as an interest rate. The Private Rate of Return to a university degree is the annual percentage return the graduate receives over their working career. In this study, six percent per annum or three percent in real terms (with safety) is considered as a benchmark for comparison of investment returns. This is the level of return that an individual would receive if they invested their money in Government bonds. If the PRR is above this level, then it could be considered that the graduate has made a worthwhile decision from a financial point of view to undertake higher education.

\section{BACKGROUND}

There have been a number of studies that have measured the rate of return to a university degree in Australia, but caution is needed in interpreting these results. This is because there are four main time frames of higher education policy in which these studies have been conducted. Studies, such as Miller (1982), that were conducted during the period of 'free' education suggest that higher education is a profitable investment, with the return greater than any alternative investments available to students at the time. Miller (1982) also found that the PRR to higher education was greater for females than males and higher for three-year than four-year degrees. Even though Miller (1982) constructed age earning profiles for both males and females based on 1976 ABS Census data and calculated the PRR for various levels of educational attainment, he did not calculate the rate of return for different types of marital status. The PRR for an Australian born male and Australian born female during the period of 'free' education were 21.10 and 21.20 , respectively (Table 1 ). 
Table 1: Studies Measuring The PRR To A University Degree

\begin{tabular}{|c|c|c|c|}
\hline Study & PI & & $\begin{array}{c}\text { Assumption } \\
\end{array}$ \\
\hline \multirow[t]{2}{*}{ Miller (1982) } & Male & 21.10 & \multirow{2}{*}{-Australian born male and females } \\
\hline & Female & 21.20 & \\
\hline \multirow[t]{4}{*}{ Maglen (1994) } & \multirow{2}{*}{ Male } & $18.02(1968-69)$ & \multirow{4}{*}{$\begin{array}{l}\text {-Males and females for the years } 1968-69 \text { to } \\
1989-90 \text {. }\end{array}$} \\
\hline & & $13.48(1989-90)$ & \\
\hline & \multirow[t]{2}{*}{ Female } & $18.19(1968-69)$ & \\
\hline & & $12.05(1989-90)$ & \\
\hline \multirow[t]{2}{*}{ Chapman \& Chai (1989) } & Male & 11.01 & \multirow{2}{*}{$\begin{array}{l}\text {-Average male } \\
\text {-Average female }\end{array}$} \\
\hline & Female & 14.97 & \\
\hline \multirow[t]{2}{*}{ Chapman \& Salvage (1998) } & Male & 9.42 & \multirow{2}{*}{$\begin{array}{l}\text {-Award/Median wage } \\
\text {-Female incomes for five occupations that have } \\
\text { award wage are based on male incomes }\end{array}$} \\
\hline & Female & 5.77 & \\
\hline Borland et al. (2000) & Average PRR & 15 & -Male income \\
\hline Borland (2002) & Average PRR & 14.5 & -Male income \\
\hline Daly, Fleming \& Lewis (2004) & Average PRR & 15.9 & -Male income \\
\hline
\end{tabular}

Post-Miller (1982) studies have shown that as Australia's higher education policy developed and moved towards a user pays system, the rates of return to a university degree have fallen. Even before the introduction of Higher Education Contribution Scheme (HECS), time series studies, such as Maglen (1994), suggested that the earnings differential between individuals with post-school qualifications and those without was narrowing due to the increased supply of university graduates. This consequently raised the opportunity cost of studying at the university and reduced the benefit of obtaining a university degree. The fall in the PRR to a university degree was further hastened by the introduction of HECS. While the Miller (1982) and Maglen (1994) studies did measure the PRR for males and females, they did not measure the impact of marital status of the PRR.

Besides Maglen (1994), Chapman \& Chia (1989) is the only study during the time of uniform HECS fees to measure the impact of the introduction of HECS on the PRR of a university degree. However, the findings of this study were limited as Chapman \& Chia (1989) used data for the 'average' male and female to measure the rates of return to education. Chapman \& Chia (1989) recognize the consequence of using data for an 'average' female, which includes women who both receive and do not receive an income. Chapman \& Chia (1989) state:

Say that four out of every five graduate females earn $\$ 25,000$ per annum, with the other earning zero. The average income of the five is $\$ 20,000$ per annum which, because of the pay-back threshold of $\$ 22,000$ per annum, results in a calculation of a zero charge, even though in reality four of the women would be paying back up to $\$ 500$ in that year.

This suggests that the PRR for a female in their study would be over valued due to the lower costs that they have assumed. The findings in the studies by Chapman \& Chia (1989) and Maglen (1994) and the estimates of the rates of return from later time series studies, such as the Productivity Commission (1997), show that the PRR to a university degree declined with the introduction of HECS and that the greatest impact was for those who paid their HECS fees up-front.

The 1996-97 budgetary changes in HECS, labelled to be the most 'radical' by Chapman \& Salvage (1998), attracted a lot of attention. Most of the Australian literature measuring the impact of HECS on the rates of return to higher education was conducted during this time period. Studies including the Productivity Commission (1997), Borland et al. (2000), Borland (2002) and Chapman \& Ryan (2003) show significant declines in the rates of return to higher education after the 1996-97 increases in HECS. Borland (2002) estimated that the PRR to a three-year bachelor degree, for a hypothetical individual after the 1996-97 budgetary changes, was 14.5 percent. However, if there had been free higher education, Borland (2002) estimated that the PRR to a three-year bachelor degree would increase to 18.5 percent. Despite Borland (2002) suggesting there had been a fall in the PRR to a three-year bachelor degree of four percentage points as a result of increases in HECS fees, the Government allowed increases in HECS fees of up to 25 percent and introduced FEE-HELP in 2005. 
Except for Miller (1982) and Maglen (1994), a significant limitation of these studies is that the PRR was measured only for the average male and female after the income of an 'average' male was used to measure the females PRR. These studies did not calculate a separate PRR for females or use median income for all persons to calculate the PRR for the 'base case'; therefore, the conclusions that are drawn are for a hypothetical male. Figure 1 shows that there are considerable differences in the income profiles of males and females in Australia.

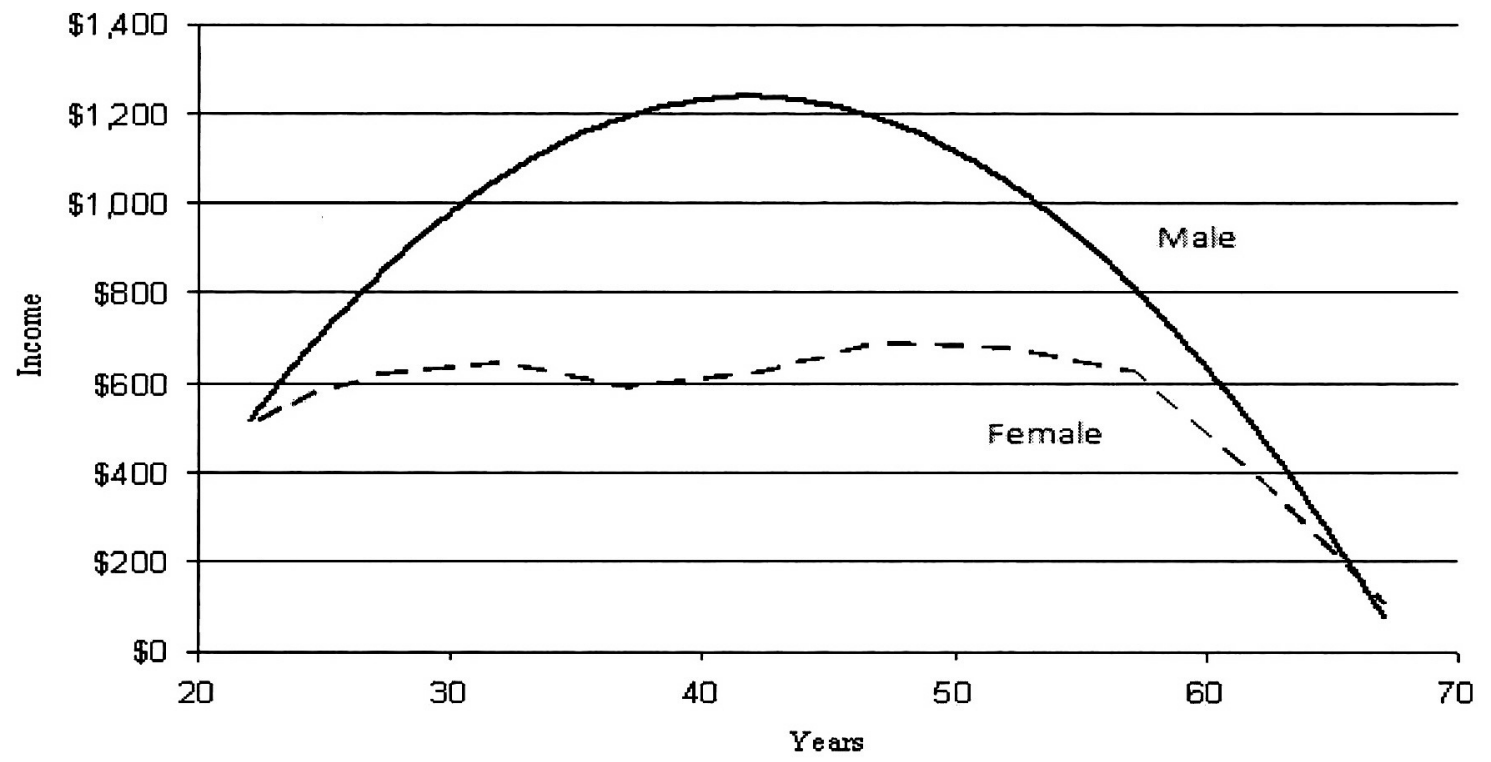

Figure 1: The Income Profiles Of Australian Male And Female University Graduates

Source: Derived from ABS Household Expenditure Survey and Survey of Income and Housing- Confidentialised Unit Record Files, 2003-04. Cat. No. 6540.0.00.001

The income profiles in Figure 1 show that the peak of a male university graduate's earnings is around 4245 years of age. This supports the study by Miller (1982) who found that the peak of the university graduate's earnings are later in their life between 45-54 years of age compared to 35-44 years for the earnings profiles of all other groups. Figure 1 also shows that the age earning profiles of females are flatter than males and double peaked around 28-32 and 48-52 years of age. Miller (1982) also discovered that the age earning profiles of females were double peaked, firstly peaking around 25 to 29 years and then declining to peak again between 50 to 54 years. As can been seen in Figure 1, the female income profile is quite different from that of the male profile as females take time out of work to have children. Studies that use the male income profile to calculate female PRR are seriously flawed in their measurements.

Except for the study by Chapman \& Salvage (1998), studies measuring the PRR to a university degree claim that the PRR for a female is higher than the PRR for a male. However, no study to date has taken into account the marital status of females when comparing the PRR to a university degree.

This article is different as it not only measures the impact of the 2005 increase in HECS changes, but also the PRR based on gender and marital status. This study will measure the PRR for both a male and female 'base case' and for differing marital status using income data from the ABS Income and Housing Survey (2003-04) CURF.

\section{METHODOLOGY OF THIS STUDY}

The Human Capital Model suggests that an individual will invest in their human capital when the costs borne immediately are worthwhile because of the return received later. The cost of a university degree is the 
opportunity cost of an individual studying at the university and the return is the income premium the university graduate receives.

The summary statistic that uses a discount rate to compare the total cost of study with the net benefits of higher education is known as the Private Rate of Return. The return on investment is only worthwhile when the Private Rate of Return is greater than the return on an alternative investment, such as the government bond rate.

The aim of this study is to measure the rate of return of a university degree for 2004 and to examine the effect that the 25 percent increase in HECS in 2005 has upon the rate of return to university graduates based on gender and marital status. Estimates of rates of return are based on the Mincer equation (Mincer, 1958). The specific rates of return in this study are calculated using Formula 1 (Borland, 2002 p. 2).

$\mathrm{PV}_{\mathrm{C}}=\sum_{\mathrm{t}=1}^{\mathrm{n}} \mathrm{C}_{\mathrm{t}}(1+\mathrm{r})^{\mathrm{t}}$

$\mathrm{PV}_{\mathrm{B}}=\sum_{\mathrm{t}=\mathrm{n}-1}^{\mathrm{m}} \mathrm{B}_{\mathrm{t}}(1+\mathrm{r})^{\mathrm{t}}$

Then:

$P V_{B}-P V_{C}=0$ and solve for $r$.

Where:

$C_{t}=$ opportunity costs for university degree in year $t$;

$B_{t}=$ benefit of university degree in year $t$;

$\mathrm{n}=$ length of education;

$\mathrm{m}-\mathrm{n}=$ years in workforce; and

$\mathrm{r}=$ rate of return.

This study measures the income of a university student, a year 12 graduate, and a university graduate based on ABS Household Expenditure Survey (HES) and Survey of Income and Housing (SIH) 2003-04 Confidentialised Unit Record Files (CURF) at person level. The study uses person level rather than income unit level data as it takes into consideration the participation in employment of the university graduates and year 12 leavers with no nonschool qualifications.

The ABS Household Expenditure Survey (HES) and Survey of Income and Housing (SIH) 2003-04 CURF contains a sample of dwellings surveyed throughout Australia from July 2003 to June 2004. The sample does not include non-private dwellings or dwellings in remote or Indigenous areas. Computer-assisted interviewing was used to collect information from persons aged 15 years and over in the selected households. The 22,286 persons interviewed were asked questions regarding personal and household characteristics such as, marital status, student status, qualifications, birthplace and detailed information on their income, assets and liabilities (ABS 2006).

The methodology is based on that of Borland (2002) ${ }^{1}$ except that the sample used to obtain the estimates include male and female wage and salary earners aged 18-60 years working part-time and full-time. Average earnings in the job with the main employer are calculated for disaggregated age workforce groups - 18, 19, 20, 21, $22,23,24,25-29,30-34,35-39,40-44,45-49,50-54$ and $55,56,57,58,59,60$ years.

It is assumed that age-earnings profiles derived using the 2003-04 HES and SIH CURF data apply over the future time period encompassed in this study. Real earnings growth for both high school and university graduates is assumed to be one percent per annum, equal to the average annual change in real average weekly earnings (AWE) for the years 1983 to 2005 .

\footnotetext{
${ }^{1}$ Lewis, Daly and Fleming (2004) also based their methodology on Borland's (2002) in their study of the PRR for economics degrees in Australia.
} 


\section{Measuring The Costs Of Higher Education For A Student}

The first stage in measuring the costs of higher education is to measure the income a student forgoes while studying. The net forgone student income is equal to the difference between the income of a year 12 graduate and a university student. The opportunity cost of studying at the university is the net forgone student income plus education costs, including HECS fees and tuition costs. This is represented by Areas B and C in the Human Capital Model. Table 2 provides a summary of how this is calculated in this model.

Table 2: A Summary Of The Costs Incurred While Studying at University

\begin{tabular}{|l|}
\hline Forgone income \\
\hline Income of a year 12 graduate minus \\
\hline $\begin{array}{l}\text { The income a student earns while studying (including employee earnings and income from scholarships and youth } \\
\text { allowance) }\end{array}$ \\
\hline Education expenses \\
\hline HECS plus \\
\hline Tuition expenses \\
\hline Total Expenses \\
\hline Forgone income plus \\
\hline Education expenses
\end{tabular}

\section{Income Of A Student}

The weekly earnings for both male and female full-time university students for the ages 18 to 24 years were measured using Ordinary Least Squares (OLS) regression analysis. The formula used to calculate this is:

$$
L w_{4}=\beta_{0}+\beta_{1} A+\beta_{2} F+\beta_{3} P T+\beta_{4} E+\beta_{5} N+\mu
$$

where $\mathrm{Lw}=\log$ of earnings in year $\mathrm{t}, \beta_{0}=\mathrm{a}$ constant term, $\mathrm{A}=$ age in years, $\mathrm{F}=$ dummy variable for female, $\mathrm{P} / \mathrm{T}=$ dummy variable for part-time work, $E=$ dummy variable for country of birth (English speaking excluding Australia), $\mathrm{N}=$ dummy variable for country of birth (non-English speaking), and $\mu=$ error term.

The regression equation does not include occupations or industries as the sample sizes available in the CURF for the classifications were too small. The base case in this model is that for a single male student who was born in Australia and works full-time.

In calculating the log of earnings for full-time students, the student income is weighted according to the proportion of students who worked part-time and not in paid employment. For those students who were not in paid employment, their income was zero. The calculation of earnings for a full-time student does not consider those students who study full-time and work full-time ${ }^{2}$.

The weekly employee incomes of university students for the ages 18 to 24 years were then multiplied by 52 to give annual gross employee income ${ }^{3}$. The employee incomes of the university students were then adjusted for real income growth of one percent per annum equal to the average annual change in real average weekly earnings (AWE) for the years 1983 to 2005. This one percent real income growth is applied from the second year of study for 2004 and from the first year of study in 2005. This real adjusted annual employee income was then added to the income a student receives from youth allowance and scholarships (based on the CURF sample) and then adjusted for tax (refer to Tables 3 and 4).

\footnotetext{
${ }^{2}$ Due to both the limited sample size and some ambiguity in the CURF identifier, education status, the earnings for both parttime and full-time students could not be calculated accurately, so this alternative approach was taken.

${ }^{3}$ The sample included the average earnings of people working over 52 weeks.
} 
Table 3: Individual Income Tax Rates For 2003-04

\begin{tabular}{|l|l|}
\hline Taxable income & Tax in this income \\
\hline$\$ 0-\$ 6000$ & Nil \\
\hline$\$ 6001-\$ 21,600$ & 17 cents for each $\$ 1$ over $\$ 6000$ \\
\hline$\$ 21,601-\$ 52,000$ & $\$ 2,652+30$ cents for each $\$ 1$ over $\$ 21,600$ \\
\hline$\$ 52,001-\$ 62,500$ & $\$ 11,772+42$ cents for each $\$ 1$ over $\$ 52,000$ \\
\hline$\$ 62,501$ and over & $\$ 16,182+47$ cents for each $\$ 1$ over $\$ 62,500$ \\
\hline
\end{tabular}

Source: Adapted from ATO (2006)

Table 4: Individual Income Tax Rates For 2004-05

\begin{tabular}{|l|l|}
\hline Taxable income & Tax in this income \\
\hline$\$ 0-\$ 6000$ & Nil \\
\hline$\$ 6001-\$ 21,600$ & 17 cents for each $\$ 1$ over $\$ 6000$ \\
\hline$\$ 21,601-\$ 58,000$ & $\$ 2,652+30$ cents for each $\$ 1$ over $\$ 21,600$ \\
\hline$\$ 58,001-\$ 70,000$ & $\$ 13,572+42$ cents for each $\$ 1$ over $\$ 58,000$ \\
\hline$\$ 70,001$ and over & $\$ 18,612+47$ cents for each $\$ 1$ over $\$ 70,000$ \\
\hline
\end{tabular}

Source: Adapted from ATO (2006)

\section{The Income Of A Year 12 Graduate With No Post-School Qualifications For Ages 18-24 Years}

To calculate the forgone income of studying at the university, the differences between the student income and the earnings of a full-time worker are measured. The OLS regression equation for a male year 12 graduate with no post-school qualifications for the ages 18 to 24 years is equation 3 :

$$
L w_{1}=\beta_{0}+\beta_{1} A+\beta_{2} A^{2}+\beta_{3} P T+\beta_{4} E+\beta_{3} N+\sum_{j=1}^{9} \alpha_{j} O_{j}+\sum_{j=1}^{16} \theta_{j} I_{j}+\sum_{j=1}^{3} \pi_{j} S_{j}+\mu
$$

where $\mathrm{Lw}=\log$ of earnings in year $\mathrm{t}, \beta_{0}=\mathrm{a}$ constant term, $\mathrm{A}=$ age in years, $\mathrm{A}^{2}=$ age squared in years, $\mathrm{P} / \mathrm{T}=$ dummy variable for part-time work, $E=$ dummy variable for country of birth (English speaking excluding Australia), $\mathrm{N}=$ dummy variable for country of birth (non-English speaking), $\mathrm{O}=$ nine dummy variables for occupations, $I=16$ dummy variables for industry, $S=$ three dummy variables for income unit status and $\mu=$ error term.

The base case is a single male without dependent children who is born in Australia. The person works fulltime as a professional in the industry category, property and business services.

Separate regression equations were also created for females for the ages 18-24 years. The only difference between the regression equations for males and females is for females, the coefficient age cubed was included in the regression equation. For males, the lifetime earnings profile forms a quadratic polynomial where, in general, income increases over time; however, for females, their lifetime earnings forms a cubic polynomial characterized by interruptions, such as child rearing.

The OLS regression equation for a female year 12 graduate with no post-school qualifications for the ages 18 to 24 years is equation 4 :

$$
L w_{t}=\beta_{0}+\beta_{1} A+\beta_{2} A^{2}+\beta_{3} A^{3}+\beta_{4} P T+\beta_{5} E+\beta_{6} N+\sum_{j=1}^{9} \alpha_{j} O_{j}+\sum_{j=1}^{16} \theta_{j} I_{j}+\sum_{j=1}^{3} \pi_{j} S_{j}+\mu
$$

where $\mathrm{LW}=\log$ of earnings in year $t, \beta_{0}=$ a constant term, $A=$ age in years, $A^{2}=$ age squared in years, $A^{3}=$ age cubed in years, $\mathrm{P} / \mathrm{T}=$ dummy variable for part-time work, $\mathrm{E}=$ dummy variable for country of birth (English speaking excluding Australia), $\mathrm{N}=$ dummy variable for country of birth (non-English speaking), $\mathrm{O}=$ nine dummy 
variables for occupations, $I=16$ dummy variables for industry, $S=$ three dummy variables for income unit status and $\mu=$ error term.

The base case is a single female with no dependents who is born in Australia. The person works full-time as a professional in the industry category, property and business services.

\section{Education Expenses}

The opportunity cost of a university education consists of HECS, forgone income, books, tuition and extra travel. The Department of Education, Science and Training's student contribution tables for 2004 and 2005 are used to determine the level of HECS a student pays to study at the university. This model calculates the return of a university degree for both students who pay their HECS fees up-front and for those students who defer their HECS debt.

\section{Up-Front Model}

For the base case, it is assumed that the student pays band two level of HECS up-front (with 25 percent discount and 20 percent discount, respectively) at $\$ 4,025.25$ for 2004 and $\$ 5,479.20$ for $2005^{4}$. It is also assumed that students in 2005 pay 25 percent higher HECS fees, as a result of the higher education policy changes (Table 5).

Table 5: Student Contribution Levels For Commonwealth Supported Places For 2004 And 2005

\begin{tabular}{|l|l|l|}
\hline Student contribution band & $\mathbf{2 0 0 4}$ & $\begin{array}{l}\mathbf{2 0 0 5} \text { including 25\% } \\
\text { higher fees } \\
\text { indexed for 2005 }\end{array}$ \\
\hline Band three (Law, Dentistry, Medicine, Veterinary Science) & $\$ 6283$ & $\$ 8018$ \\
\hline $\begin{array}{l}\text { Band two (Accounting, Administration, Economics, Commerce, } \\
\text { Mathematics, Statistics, Computing, Built Environment, Health, } \\
\text { Engineering, Science, Surveying, Agriculture) }\end{array}$ & $\$ 5367$ & $\$ 6849$ \\
\hline $\begin{array}{l}\text { Band one (Humanities, Behavioural Science, Social Studies, } \\
\text { Foreign Languages, Visual and Performing Arts) }\end{array}$ & $\$ 3768$ & $\$ 4808$ \\
\hline National priorities (Education, Nursing) & $\$ 3768$ & $\$ 3847$ \\
\hline Up-front discount & 25 percent & 20 percent \\
\hline
\end{tabular}

Source: Modified from AVCC (2006)

\section{Deferred Model}

In addition to measuring the rate of return for students who pay their HECS fees up-front, a separate model has been constructed to measure the rate of return for the 75 percent of students who defer the HECS repayments (DEST 2004) ${ }^{5}$. In order to estimate the compulsory level of HECS repayments the graduate must pay each year, Table 4 is used. In the deferred model, there is no discount and graduates make their repayments when they reach the income threshold.

In measuring education expenses in both models, the cost of books, tuition and extra travel are equal to Borland's (2002) estimation, indexed to the CPI Tertiary Education Cost Index. The student outlay for books, tuition and extra travel for 2004 is $\$ 2,289$ and $\$ 2,360$ for 2005 , adjusted in real terms. This is supported by the University of New South Wales (2006) which estimates that the cost of textbooks is a minimum of $\$ 500$ per year, the cost of field trips and equipment is approximately $\$ 1,000$ per year, and the annual fee for university guilds and sports associations is $\$ 513.60$. In addition to these costs is the fee for student parking at $\$ 8.00$ per day or $\$ 960$ per annum ${ }^{6}$.

\footnotetext{
${ }^{4}$ Borland (2002) also assumed students paid band two level of HECS.

${ }^{5}$ DEST (2004) found that in 2004, 413,085 students of the 550,579 students attending university opted to defer their HECS liabilities.

${ }^{6}$ The annual figure for student parking assumes that the student attends university for four days per week, for 30 weeks in the year.
} 


\section{Private Rate Of Return}

According to Human Capital Theory, an individual's level of income is directly related to their level of education and experience. The Human Capital Model suggests that an individual with a university degree will receive a higher income over their lifetime compared to an individual who has only completed year 12 .

\section{Income Of A University Graduate And Year 12 Graduate With No Post-School Qualifications For The Ages 21 To 60 Years}

To estimate the log of earnings for both, a year 12 graduate and a university graduate for the ages 21 to 60 years, separate OLS regression equations were formed for males and females.

The OLS regression equation for a male, including both university graduates and year 12 graduates with no post-school qualifications for the ages 21 to 60 years, is equation 5:

$$
\begin{aligned}
& L w_{\text {tm }}=\beta_{0}+\beta_{1} A+\beta_{2} A^{2}+\beta_{3} A^{3}+\beta_{4} P T+\beta_{5} B+\beta_{6} E+\beta_{7} N+\sum_{j=T}^{3} \tau_{j} L_{j}+\sum_{j=T}^{8} \alpha_{j} O_{j}+\sum_{j=1}^{16} \theta_{j} I_{j} \\
& +\sum_{j=1}^{3} \pi_{j} S_{j}+\sum_{j=1}^{11} \sigma_{j} N S_{j}+\mu
\end{aligned}
$$

where $L w=\log$ of earnings in year $t, \beta_{0}=a$ constant term, $A=$ age in years, $A^{2}=$ age squared in years, $A^{3}=$ age cubed in years, $\mathrm{P} / \mathrm{T}=$ dummy variable for part-time work, $\mathrm{B}=$ dummy variable for left before year $12, \mathrm{E}=$ dummy variable for country of birth (English speaking excluding Australia), $\mathrm{N}=$ dummy variable for country of birth (nonEnglish speaking), $\mathrm{L}=$ three dummy variables for level of non-school qualification, $\mathrm{O}=$ eight dummy variables for occupations, $\mathrm{I}=16$ dummy variables for industry, $\mathrm{S}=$ three dummy variables for income unit status, NS $=11$ dummy variables for non-school qualifications and $\mu=$ error term.

The base case is for a sole person with no dependents who completed year 12 and is born in Australia. The person has a bachelor degree in management and commerce and works full-time as a professional in the industry category, property and business services.

A separate equation was used to measure the income of female university graduates and year 12 graduates with no post-school qualifications for ages 21 to 60 years.

The OLS regression equation for female university graduates and year 12 graduates with no post-school qualifications for the ages 21 to 60 years is equation 6 :

$$
\begin{aligned}
& L w_{m}=\beta_{0}+\beta_{1} A+\beta_{2} A^{2}+\beta_{3} A^{3}+\beta_{4} P T+\beta_{i} B+\beta_{6} E+\beta-N+\sum_{j=1}^{3} \tau_{j} L_{j}+\sum_{j=1}^{s} \alpha_{j} O_{j}+\sum_{j=1}^{16} \theta_{j} I_{j} \\
& +\sum_{j=1}^{3} \pi_{j} S_{j}+\sum_{j=1}^{11} \sigma_{j} N S_{j}+\mu
\end{aligned}
$$

The base case is for a sole person with no dependents who completed year 12 and is born in Australia. The person has a bachelor degree in management and commerce and works full-time as a professional in the industry category, property and business services.

The earnings of both the year 12 graduate and the university graduate are then multiplied by 52 to give the annual gross employee earnings. The earnings are then adjusted for real income growth of one percent per annum. These earnings are then adjusted for employment probability. The unemployment rates for 2004 for a university graduate and year 12 graduate with no post-school qualifications are 3.0 percent and 6.56 percent, respectively. This is based on the unemployment rate for those categories in 2004 (ABS, 2004). To allow for limitations of the Human Capital Model, such as screening effects and innate ability, the difference between a university graduate's income and year 12 graduate's income is multiplied by 80 percent (Ashenfelter \& Krueger, 1994). Sensitivity analysis will 
later be applied to measurements at a 90 percent and a 100 percent level. The tax payable is calculated for each year using the ATO 2003-04 and 2004-05 income tax tables shown in Table 2 and Table 3.

\section{Calculating The Private Rate Of Return Model}

For all rates of return females and males are measured separately based on their separate income profiles. The base case scenario is for an 18 year old individual studying a three year bachelor degree in commerce in 2004 who enters the workforce at the age of 21 in 2007. It is assumed that the student will pay band two level of HECS up-front and retire at 60 years of age.

\section{RESULTS}

The Private Rates of Return measure the impact that the 2005 increases in HECS had upon the PRR to a university degree for types of marital status. The rates of return are limited to those students enrolled in Commonwealth Supported Place (CSP). This study measures the PRR for both students who pay their HECS fees up-front and for those who defer their HECS repayments. Sensitivity analysis has been used to allows measurements at the $80 \%, 90 \%$, and $100 \%$ levels.

\section{Up-Front Model}

Male

The results in Table 6 show the PRR to a university degree for males of different marital status who pay their HECS fees up-front. As seen in Table 6, the highest PRR to a university degree for males is for married males with no dependent children at 12.36 percent (at the 80 percent level for 2005). The lowest return is for a single male with dependent children at 8.82 percent (at the 80 percent level for 2005). These results suggest that studies measuring the PRR to a university degree for a single male with no dependents underestimate the return males receive. This study shows that in 2005 the PRR for married males with no dependent children is 3.28 percentage points higher than the PRR for a single male with no dependents.

The results in Table 6 also show that for all males who pay their HECS fees up-front, the PRR to a university degree has decreased in 2005. For example, the PRR for a married male with no dependent children decreased from 12.74 percent in 2004 to 12.36 percent in 2005 (at the 80 percent level), while the PRR for a single male with dependent children decreased from 9.11 percent in 2004 to 8.82 percent in 2005 (at the 80 percent level).

Studies such as Breusch \& Gray (2004), Lincoln (2008) and Western, and Hewitt \& Baxter (2005) have found that there are significant marriage premiums for men. The study by Breusch \& Gray (2004) found that married men earn at least $\$ 2.00$ per hour more than non-married men and Lincoln (2008 p. 806) states that 'the hourly wages of married men are generally 10 to 40 percent more than those earned by never-married men'. Western, Hewitt \& Baxter (2005) found that even after male incomes were adjusted for human capital, job and family characteristics, Australian married men earned approximately $\$ 5,700$ more per annum then unmarried men.

Table 6: The PRR To A University Degree For Males Who Pay Their HECS Fees Up-Front For 2004 And 2005 (Based On Marital Status)

\begin{tabular}{|l|l|l|l|}
\hline & \multicolumn{3}{|l|}{ Private Rate of Return } \\
\hline Year & $\mathbf{1 0 0}$ percent & $\mathbf{9 0}$ percent & $\mathbf{8 0}$ percent \\
\hline 2004 & & & \\
\hline Lone person with no dependent children & 11.46 & 10.44 & 9.37 \\
\hline Lone person with dependent children & 11.15 & 10.15 & 9.11 \\
\hline Married with no dependent children & 15.36 & 14.07 & 12.74 \\
\hline Married with dependent children & 15.29 & 14.01 & 12.67 \\
\hline 2005 & & & \\
\hline Lone person with no dependent children & 11.08 & 10.10 & 9.08 \\
\hline Lone person with dependent children & 10.79 & 9.83 & 8.82 \\
\hline Married with no dependent children & 14.88 & 13.64 & 12.36 \\
\hline Married with dependent children & 14.81 & 13.58 & 12.30 \\
\hline
\end{tabular}


The two main theoretical explanations supporting the large 'marriage premium' for men are the 'specialization hypothesis' and 'selection hypothesis', both relating to productivity and both derived from Becker's sexual division of labor (1985). The 'specialization hypothesis' suggests that marriage allows men to specialize in the labor market, making them more productive in paid work because their wives specialize in traditional responsibilities. The competing explanation, the 'selection hypothesis' reverses the direction of causality. The 'selection hypothesis' proposes that successful men with greater levels of human capital are more likely to be married. This hypothesis suggests that married men are more productive than non-married men before they get married rather than marriage causing men to become more productive. Breusch \& Gray (2004) argue that this is not as widely supported in the literature as the 'specialization hypothesis'. Irrespective of which line of thought one might follow, this study shows that there are significant differences between the benefits of a university education to different marital status for males in Australia.

\section{Female}

This study also measured the PRR to a university degree for females of different marital status who pay their HECS fees up-front. The results in Table 7 show that marital status has a significant impact on the return to higher education for females. The results also show that not the same type of marital status is favourable to both males and females. For example, in 2005 for females, the highest PRR of a university degree is for a single female with no dependent children at 12.69 percent (at the 80 percent level), whereas for males, the highest PRR to a university degree is for married males with no dependent children.

The results in this study also show that the lowest PRR to a university degree, out of all persons, is for a single female with dependent children at 8.09 percent (at the 80 percent level for 2005). In 2005, the PRR to a university degree for a single female with dependents is 4.60 percentage points lower than the PRR for single females with no dependents (at the 80 percent level). The results in this study suggest that the marital status of a lone person with dependent children is more detrimental to the PRR for females than males, given the PRR for single males with dependent children is only 0.26 percentage points lower than the PRR for males with no dependent children.

Table 7: The PRR To A University Degree For Females Who Pay Their Hecs Fees Up-Front For 2004 And 2005 (Based On Marital Status)

\begin{tabular}{|l|l|l|l|}
\hline & \multicolumn{3}{|c|}{ Private Rate of Return } \\
\hline Year & $\mathbf{1 0 0}$ percent & $\mathbf{9 0}$ percent & $\mathbf{8 0}$ percent \\
\hline 2004 & & & \\
\hline Lone person with no dependent children & 15.98 & 14.70 & 13.38 \\
\hline Lone person with dependent children & 10.31 & 9.46 & 8.56 \\
\hline Married with no dependent children & 15.38 & 14.15 & 12.88 \\
\hline Married with dependent children & 11.26 & 10.34 & 9.37 \\
\hline 2005 & & & \\
\hline Lone person with no dependent children & 15.14 & 13.94 & 12.69 \\
\hline Lone person with dependent children & 9.76 & 8.95 & 8.09 \\
\hline Married with no dependent children & 14.56 & 13.41 & 12.21 \\
\hline Married with dependent children & 10.66 & 9.79 & 8.87 \\
\hline
\end{tabular}

The results in Table 7 show that, like males, the PRR to a university degree for females who pay their HECS fees up-front has decreased in 2005. For example, the PRR for a single female with no dependent children decreased from 13.38 percent in 2004 to 12.69 percent in 2005 (at the 80 percent level), while the PRR for a single female with dependent children decreased from 8.56 percent in 2004 to 8.09 percent in 2005 (at the 80 percent level). In 2005, the PRR for a single female with dependent children enrolled in a Commonwealth Supported Place (CSP), who pays her HECS fees up-front, is 3.99 percentage points lower than the PRR for a single female with no dependent children enrolled in FEE-HELP position (at the 80 percent level) in the 'average' degree. This suggests that certain socially disadvantaged groups, such as single parents, are gaining the least from the current HECS system. 
These results also suggest that if studies conclude that the return to a university degree is higher for females than males, then these studies may only be taking into account the marital status of a lone person with no dependents. For all forms of marital status, other than a lone person with no dependents, males have a higher PRR than females.

\section{Deferred Model}

Male

The Private Rates of Return to higher education for males of different marital status, who defer their HECS repayments, are shown in Table 8. The results show that for all males, the PRR is higher when they choose to defer their HECS repayments, rather than pay their HECS fees up-front. For example, for married males with no dependent children, the PRR for those who defer their HECS repayments is 13.59 percent, whereas for those who pay their HECS fees up-front, their PRR is 12.36 percent (at the 80 percent level for 2005).

The results in Table 8 also show that for all males who defer their HECS fees, their PRR rises in 2005, even after the 25 percent increases in HECS. This is partly because of the changes to the HECS repayment system reducing the cost of study in discounted terms. For example, a single male with dependent children studying a threeyear degree in 2004 would repay his HECS debt back by the age of 27 years. However, the increase in the income threshold in 2005 has resulted in the single male with dependent children not repaying his HECS debt back until he is 29 years old. A similar pattern also occurred in the other categories.

Table 8: The PRR To A University Degree For Males Who Defer Their HECS Fees For 2004 And 2005 (Based On Marital Status)

\begin{tabular}{|l|l|l|l|}
\hline \multicolumn{3}{|c|}{ Private Rate of Return } \\
\hline Year & $\mathbf{1 0 0}$ percent & $\mathbf{9 0}$ percent & $\mathbf{8 0}$ percent \\
\hline 2004 & & & \\
\hline Lone person with no dependent children & 11.88 & 10.92 & 9.92 \\
\hline Lone person with dependent children & 11.55 & 10.61 & 9.63 \\
\hline Married with no dependent children & 16.05 & 14.82 & 13.52 \\
\hline Married with dependent children & 15.99 & 14.76 & 13.47 \\
\hline 2005 & & & \\
\hline Lone person with no dependent children & 11.90 & 10.96 & 9.96 \\
\hline Lone person with dependent children & 11.57 & 10.65 & 9.68 \\
\hline Married with no dependent children & 16.09 & 14.87 & 13.59 \\
\hline Married with dependent children & 16.01 & 14.79 & 13.52 \\
\hline
\end{tabular}

Female

Table 9 shows the Private Rates of Return to higher education for females of different marital status who defer their HECS repayments. The results in Table 9 show that, as was the case for males, the PRR is higher for females who defer their HECS repayments than for those who pay their HECS fees up-front. For example, in 2005 the PRR for a single female with dependent children is 9.18 percent, if she chooses to defer her HECS repayments (Table 9), or 8.09 percent is she chooses to pay her HECS fees up-front (at the 80 percent level). 
Table 9: The PRR To A University Degree For Females Who Defer Their HECS Fees For 2004 and 2005 (Based On Marital Status)

\begin{tabular}{|l|l|l|l|}
\hline \multicolumn{3}{|c|}{ Private Rate of Return } \\
\hline Year & $\mathbf{1 0 0}$ percent & $\mathbf{9 0}$ percent & $\mathbf{8 0}$ percent \\
\hline 2004 & & & \\
\hline Lone person with no dependent children & 17.23 & 15.98 & 14.68 \\
\hline Lone person with dependent children & 10.87 & 10.09 & 9.25 \\
\hline Married with no dependent children & 16.57 & 15.37 & 14.12 \\
\hline Married with dependent children & 11.94 & 11.08 & 10.17 \\
\hline 2005 & & & \\
\hline Lone person with no dependent children & 17.14 & 15.91 & 14.63 \\
\hline Lone person with dependent children & 10.76 & 9.99 & 9.18 \\
\hline Married with no dependent children & 16.45 & 15.27 & 14.04 \\
\hline Married with dependent children & 11.87 & 10.98 & 10.09 \\
\hline
\end{tabular}

The results in this study suggest that, on average, CSP students, regardless of their marital status, should consider their payment options carefully, as the PRR is higher for those who defer their HECS repayments than for those who pay their HECS fees up-front. Contrary to males, Table 9 shows that the PRR to a university degree for females falls after the 2005 budgetary changes in HECS. This suggests that the 25 percent increase in HECS fees has had a more adverse impact on the PRR to a university degree for females than males. The results in this study also show that for both females who paid their HECS fees up-front (Table 7) and females who deferred their HECS repayments (Table 9), their PRR fell in 2005. These findings also suggest that the gap between the PRR between males and females who defer their HECS fees has closed as a consequence of the 2005 HECS changes. For example, the PRR for married females with no dependent children who deferred their HECS repayments, decreased from 14.12 percent in 2004 to 14.04 percent in 2005 . Meanwhile, the PRR for married males with no dependent children, who deferred their HECS repayments, increased from 13.52 percent to 13.59 percent.

However, caution is needed with interpreting the estimates in Table 9 as the rates of return are assuming that the female graduate will repay her HECS debt and not leave the workforce. For example, a single female with dependent children, who chooses to defer her HECS repayments in 2005, will not repay her HECS debt until she is 32 years of age. This assumes that the single female with dependent children upon graduating will work full-time and will not have any work interruptions. However, in reality, at times females will either work part-time or not work at all and will therefore not reach the income threshold to repay their HECS debt. According to Standfield (2003 p. 1), only 77 percent of females pay back all of their HECS debt by the time they are 65 years of age compared to 93 percent of men. An area of further study would be to measure the impact of HECS on the PRR for a university degree for women who follow different employment paths as a result of marital status and dependent children.

\section{CONCLUSION}

A significant limitation of previous Australian studies was that most studies (Table 1) only measured the PRR for the average male and average female using the income profile of a male. Figure 1 demonstrates that the income profiles of males and females are quiet different, largely due to child rearing responsibilities, and as a result, should be measured independently. Most of those studies showed that the PRR to a female was greater than that of a male. This study measures the PRR of an average degree for different types of marital status using separate male and female profiles. The findings of this study found that the PRR for a female is only higher than the PRR for a male for the marital status, lone person with no dependents. For instance, for all males who pay their HECS fees up-front, except for single males with no dependents, the PRR is greater for males than females. For example, in 2005 the PRR for a married male with dependent children, who pays their HECS fees up front, is 12.30 percent, whereas the PRR for a married female with dependent children who pays their HECS fees up front is 8.87 percent (at the 80 percent level). In 2005, the highest PRR for both males, who defer their HECS repayments and for those who pay their HECS fees up front, is for the marital status, married with no dependent children at 12.36 percent and 13.59 percent, respectively (at the 80 percent level). Meanwhile, the highest PRR for females is for a lone person with no dependent children at 12.69 percent and 14.63 percent respectively (at the 80 percent level for 2005). These results 
suggest that studies that measure the PRR to a university degree for single males and single females with no dependent children underestimate the PRR for most male graduates and overestimate the PRR of female graduates.

For all males and all females who paid their HECS fees up front, the PRR to an average degree decreased in 2005. In 2005, the lowest PRR to a university degree was for single females with dependent children at 8.09 percent or 4.60 percentage points lower than the PRR for single females with no dependent children (at the 80 percent level). In 2005, the PRR for a single female with dependent children, enrolled in a Commonwealth Supported Place and who paid her HECS fees up-front, was 3.99 percentage points lower than the PRR for a single female with no dependents in a FEE-HELP position. This suggests that certain socially disadvantaged groups, such as single parents, are gaining the least from the HECS system. Despite the 2005 increases in HECS, the PRR for single females with dependent children, who paid their HECS fees up front, is still higher than the real interest rate and could be considered a worthwhile investment.

For all males, who deferred their HECS repayments, the 2005 budgetary changes in HECS appeared to have no affect on the PRR to an average degree, whereas for all females, who deferred their HECS repayments, the PRR decreased in 2005. For example, the PRR to an average degree for single males with no dependents increased from 9.92 percent in 2004 to 9.96 percent in 2005 (at the 80 percent level). Meanwhile, the PRR for single females with no dependents decreased from 14.68 percent in 2004 to 14.63 percent in 2005 (at the 80 percent level). This suggests that the gap between the PRR between males and females who defer their HECS fees has closed as a result of the 2005 changes in HECS. It is likely that further increases in HECS fees are likely to not only lower the PRR for higher education, but also disadvantage women more than men.

\section{AUTHOR INFORMATION}

Dr Sarah Wright is a lecturer in economics at the Australian Catholic University in Sydney. She has written extensively on higher education policy especially in regards to equity and efficiency and was awarded a Faculty of Arts and Sciences Teaching Award in 2010.

\section{REFERENCES}

1. Ashenfelter, O. and Krueger, A. (1994). Estimates of the return to schooling from a new sample of twins. American Economic Review, 84(5), 1157-1173.

2. Australian Bureau of Statistics (ABS). (2004). Education and Work. Cat. No. 6227.0 Canberra, Australian Bureau of Statistics.

3. Australian Bureau of Statistics (ABS). (2006). Household Expenditure Survey and Survey of Income and Housing-Confidentialised Unit Record Files, 2003-04. Cat. No. 6540.0.00.001 Canberra, Australian Bureau of Statistics.

4. Australian Taxation Office (ATO). (2006). Individual income tax rates for prior years. Canberra, Australian Taxation Office. Viewed: $2^{\text {nd }}$ November 2006, http://www.ato.gov.au/individuals/content.asp?doc=/Content $/ 73969 . \mathrm{htm}$

5. Australian Vice-Chancellor's Committee. (AVCC). (2006). History of HECS. Canberra, Australian Vice-Chancellor's Committee. Viewed: $9^{\text {th }}$ November 2006, http://www.avcc.edu.au/documents/publications/stats/History-of-HECS-April2006.xls

6. Becker, G. (1985). Human capital, effort, and the sexual division of labor. Journal of Labor Economics 3(1), 33-58.

7. Borland, J. (2002). New estimates of the private rate of return to university education in Australia. Melbourne, Department of Economics, University of Melbourne.

8. Borland, J. Dawkins, P. Johnson, D. and Williams, R. (2000). Returns to investment in higher education. Melbourne, Melbourne Economics of Higher Education Research Program Report no. 1, University of Melbourne. Viewed: $20^{\text {th }}$ June 2005, http://melbourneinstitute.com/publications/reports/rihe.pdf

9. Breusch, T. and Gray, E. (2004). Does marriage improve the wages of men and women in Australia? Canberra, Australian Population Association. Viewed: $6^{\text {th }}$ February 2010, http://www.apa.org.au/upload/2004-7D Breusch.pdf 
10. Chapman, B. and Chia, T. (1989). Financing higher education: Private rates of return and externalities in the context of the tertiary tax. Canberra, Centre for Economic Policy Research and Department of Economics, ANU. Discussion paper no. 213.

11. Chapman, B. and Ryan, C. (2003). Higher education financing and student access: A review of the literature. Canberra, Economic Program, Research School of Social Sciences, Australian National University. Viewed: $29^{\text {th }}$ April 2005 , http://www.avcc.edu.au/documents/policies_programs/statements/Chapman_HECS_study_Oct0 3.pdf

12. Chapman, B. and Salvage, T. (1998). Changes in the cost for Australian higher education students from the 1996/97 Budget. Hochschulfinanzierung (Austrian Journal of Public Policy Higher Education Funding issue), 4 (1998), 71-90.

13. Chia, T. (1990). Returns to higher education. PhD thesis. Canberra, Australian National University.

14. Chia, T. (1991). Has the value of a degree fallen? Cross-sectional versus time-series evidence. The Economic Record, (1991), 41-52.

15. Daly, A. Fleming, D. and Lewis, P. (2006) A cohort analysis of the private rate of return to higher education in Australia. Australian Journal of Labor Economics, 9 (3), 257-268.

16. Department of Education, Science and Training (DEST). (2004). Actual student load (EFTSU) for all students by liability status, state and institution 2004. Canberra, Department of Education, Science and Training. Viewed: $2^{\text {nd }}$ September 2005, http://www.dest.gov.au/sectors/higher education/publications resources/statistics/documents/stu dents 2004 first half year.htm

17. Lewis, P. Daly, A. and Fleming, D. (2004). Why study economics? The private rate of return to an economics degree. Canberra, The Centre for Labor Market Research, University of Canberra. Viewed: $16^{\text {th }}$ November 2005, http://www.business.curtin.edu.au/files/04_5.pdf

18. Lincoln, A. (2008). Gender, productivity and the marital wage premium. Journal of Marriage and Family, $70(3), 806-814$.

19. Maglen, L. (1994). Education expansion and the private returns to a university degree. Economic Papers, 13 (1), 57-71.

20. Miller, P. (1982). The rate of return to education: Evidence from the 1976 Census. Australian Economic Review, $3^{\text {rd }}$ quarter, 23-32.

21. Mincer, J. (1958). Investment in human capital and personal income distribution. Journal of Political Economy, 66 (1), 281-302.

22. Productivity Commission (PC). (1997). Submission to the Review of Higher Education Financing and Policy. Canberra, Productivity Commission. Viewed: $27^{\text {th }}$ May 2005, http://www.pc.gov.au/ic/research/submission/highered/highered.pdf

23. Standfield, R. (2003). Women's department budget briefing paper. The higher education reform package-Bad for all worse for women. Melbourne, National Union of Students.

24. University of New South Wales. (2006). Future students- other study fees. Sydney, University of New South Wales. Viewed: $7^{\text {th }}$ November 2006, http://www.international.unsw.edu.au/future/fees/feesother.html

25. Western, M. Hewitt, B. and Baxter, J. (2005). Marriage and Money: Variations across the Earnings Distribution. Australian Journal of Labor Economics, 8(2), 163-179. 